\title{
Taxonomic Status of Kitasatosporia, and Proposed Unification with Streptomyces on the Basis of Phenotypic and 16S rRNA Analysis and Emendation of Streptomyces Waksman and Henrici 1943, 339 ${ }^{\mathrm{AL}}$
}

\author{
E. M. H. WELLINGTON, ${ }^{1 *}$ E. STACKEBRANDT, ${ }^{2} \dagger$ D. SANDERS, ${ }^{1}$ J. WOLSTRUP, ${ }^{3}$ aND N. O. G. JORGENSEN ${ }^{3}$
}

Department of Biological Sciences, University of Warwick, Coventry CV4 7AL, England ${ }^{1}$; Institut fur Allgemeine Mikrobiologie, Christian-Albrechts-Universitat, 2300 Kiel, Germany ${ }^{2}$; and Department of Microbiology, Institute of Ecology and Molecular Biology, Royal Veterinary and Agricultural University, DK-1958 Frederiksberg C, Denmark ${ }^{3}$

\begin{abstract}
Species classified within the genus Kitasatosporia share many of the phenotypic characteristics typical of streptomycetes. By using a probabilistic identification scheme, they were identified with Streptomyces exfoliatus cluster 5, a species group within Streptomyces. The four species studied hybridized with a 16S rRNA genus probe for Streptomyces spp., indicating a close relationship between the two genera. The kitasatosporias were resistant to selected polyvalent streptomycete phages tested. Quantitative analysis showed that mesodiaminopimelic acid varied from 49 to $89 \%$ in Kitasatosporia species and from 1 to $16 \%$ in Streptomyces species depending on growth conditions. On the basis of $16 \mathrm{~S}$ rRNA analysis, it is proposed to reduce Kitasatosporia to synonymy with Streptomyces. As a result, the new names proposed are Streptomyces mediocidicus comb. nov., Streptomyces phosalacineus comb. nov., Streptomyces setae comb. nov., and Streptomyces griseolosporeus comb. nov., nom. nov.
\end{abstract}

The genus Kitasatosporia was proposed to include newly isolated actinomycete strains which contained similar amounts of LL and meso isomers of diaminopimelic acid (DAP) and also glycine and galactose in their cell walls (9). Further analysis revealed that most of the LL-DAP was in the aerial mycelium, and the meso-DAP was in the vegetative mycelium (15). The morphology and physiology of the strains were characteristic of Streptomyces spp., but submerged growth resulted in production of sporelike cells which contained LL-DAP, whereas the mycelium contained meso-DAP (15). Labeda (5) described a new species, Kitasatosporia mediocidica, which contained both LL- and mesoDAP and showed traces of glycine in whole-cell hydrolysates. The sugars galactose and rhamnose were also detected. Further species were described but they had more LL- than meso-DAP (ratio of 3:1) (7). The cell wall typical of Streptomyces spp. contains major amounts of LL-DAP with glycine, wall chemotype 1 (1), although minor amounts of meso-DAP can be detected.

The aim of the present study was to clarify the relationship between the genera Kitasatosporia and Streptomyces and determine if the former should be grouped with members of the family Streptomycetaceae on the basis of 16s rRNA, phage susceptibility, chemotype, and phenotype.

\section{MATERIALS AND METHODS}

Strains. $K$. griseola NRRL B-16229, $K$. mediocidica NRRL $16109^{\mathrm{T}}, K$. phosalacinea NRRL B-16230, and $K$. setae NRRL B-16185 (representing the type species) were kindly supplied by D. Labeda and preserved in $10 \%$ glycerol at $-20^{\circ} \mathrm{C}$. Other actinomycetes used for cell wall analysis are listed in Table 2.

Morphology and physiology. Strains were examined by

\footnotetext{
* Corresponding author.

† Present address: Department of Microbiology, University of Queensland, Queensland 4072, Australia.
}

using the methods of Williams et al. (19), and their phenotypes were compared with those of Streptomyces spp. by use of a probabilistic identification scheme for the major species groups (20).

Cell wall analysis. Strains were grown in shake flasks at $30^{\circ} \mathrm{C}$ for 3 days in tryptone soy broth (Oxoid) $(25 \mathrm{ml}$ in 250-ml flasks), harvested by centrifugation, and washed with distilled water and ethanol before being dried. Whole-cell hydrolysates were prepared by using $60 \mathrm{mg}$ of dried cells, and cell wall type was determined by thin-layer chromatography (14). Cells were also harvested from plate cultures grown for 2 days at $30^{\circ} \mathrm{C}$ on peptone agar containing (weight/ volume) peptone, $0.6 \%$; Bacto Casitone, $0.4 \%$; yeast extract, $0.3 \%$; glucose, $0.1 \%$; beef extract, $0.15 \%$; and agar, $2.0 \%$. For high-pressure liquid chromatography (HPLC) analysis, dried hydrolyzed samples were suspended in $10 \mathrm{ml}$ of Milli-Q water and diluted 1:3 before injection into the HPLC. LL- and meso-DAP were measured as the fluorescent $o$-phthaldialdehyde derivatives (3).

Phage typing. The polyvalent phage DP9, 102, 93, 86, 35, and 34, known to be specific for the Streptomycetaceae with cell wall chemotype 1 (17), were tested for lysis on lawns of the four Kitasatosporia species by using the methods of Wellington and Williams (17).

Isolation of crude RNA, probe synthesis, and hybridization conditions. Cells grown in shake flasks containing tryptone soy broth $(30 \mathrm{ml}$ in $100-\mathrm{ml}$ flasks) were harvested after $12 \mathrm{~h}$ by centrifugation. Isolation of crude RNA, labeling of probes, and dot blot hybridization were done as described by Stackebrandt and Charfreitag (12). Three hundred nanograms of crude RNA from each of the 4 Kitasatosporia strains and the 16 streptomycete and nonstreptomycete reference strains was hybridized with $10^{5} \mathrm{cpm}$ of ${ }^{32} \mathrm{P}$-labeled probes (depending on the specific activity, between 20 and $50 \mathrm{ng}$ of RNA). The probes were directed against specific stretches of the 16S rRNA. Hybridization was done in $6 \times$ SSC $(1 \times$ SSC is $0.15 \mathrm{M} \mathrm{NaCl}, 0.015 \mathrm{M}$ trisodium citrate, and 0.001 M EDTA, $\mathrm{pH} 7)-0.1 \%$ sodium dodecyl sulfate ( $\mathrm{pH} 7.2)$ at $28^{\circ} \mathrm{C}$ for the eubacterial consensus probe (5' CTACCAG 
TABLE 1. Identification of Kitasatosporia species by a probability matrix for $S$. exfoliatus cluster group 5 (20)

\begin{tabular}{lcc}
\hline \multirow{1}{*}{ Species } & \multicolumn{2}{c}{ Identification score } \\
\cline { 2 - 3 } & $\begin{array}{c}\text { Wilcox } \\
P\end{array}$ & $\begin{array}{c}\text { Taxonomic } \\
\text { distance } \pm \text { s.e. (d) }\end{array}$ \\
\hline K. griseola NRRL B-16229 & 0.99 & $0.43+2.3$ \\
K. mediocidica NRRL B-16109 & 0.97 & $0.44+2.48$ \\
K. phosalacinea NRRL B-16230 & 0.98 & $0.39+1.32$ \\
$K$ Setae NRRL B-16185 & 0.97 & $0.41+1.91$ \\
\hline
\end{tabular}

GGTATCTAAT 3', targeting positions 787 to 803 [Escherichia coli nomenclature]) and at $38^{\circ} \mathrm{C}$ for the Streptomycesspecific probe $\left(5^{\prime}\right.$ GCGTCGAATTAAGCCACA $3^{\prime}$, positions 950 to 967). After hybridization, filters were washed with $6 \times$ SSC for $2 \mathrm{~min}$ at room temperature and then for 15 min under more-stringent conditions to destroy unspecifically reassociated hybrids (see legend to Fig. 1). Autoradiography was for $20 \mathrm{~h}$.

Sequence homology of $16 \mathrm{~S}$ rRNA. The sequence data for the Streptomyces species were from Witt et al. $(21,22)$, and the basis for homology calculation was a reduced sequence alignment that had eliminated all the absolutely conserved positions.

Sequence data for Kitasatosporia species were provided by Martin Embley, Department of Paramedical Sciences, North East London Polytechnic, London, England.

\section{RESULTS}

Probabilistic identification. The phenotypes of the four Kitasatosporia species, all identified with the Streptomyces cluster group 5 of Williams et al. (20) (Streptomyces exfoliatus), and the identification scores show a close similarity between all four species and $S$. exfoliatus (Table 1). The results also indicate that there is phenotypic similarity among the Kitasatosporia species. The strains had a number of atypical characters; they failed to degrade xanthine or allantoin, and $K$. setae and $K$. phosalacinea were resistant to rifampin (test method of Williams et al. [20] was used). The taxonomic distance scores (Table 1) indicate that the species are not close to the centroid of the group.

Cell wall analysis. Cell wall analysis of submerged growth (3-day culture) by thin-layer chromatography revealed significant amounts of LL-DAP in all Kitasatosporia species except $K$. mediocidica. Quantification of the relative amounts of each isomer present in biomass from both liquid and solid cultures was achieved by HPLC analysis (Table 2). By using HPLC, meso-DAP was also detected in Streptomyces species at levels between 1 and $16 \%$, depending on the species analyzed. The level of meso-DAP detected in Kitasatosporia strains varied from 49 to $89 \%$, where variation was dependent on the amount of sporulation in the cultures, as previously reported for this group (15). Except for S. griseus, which can produce sporelike bodies, the Streptomyces species did not produce submerged spores. It can be concluded that under any of the conditions tested, the Kitasatosporia species always had at least three times more meso-DAP in the cells than Streptomyces species had. Within the Streptomyces genus, variations in the amounts of meso-DAP were recorded, but no clear correlation was seen with the morphological type of biomass analyzed.

The ratios of meso- to LL-DAP for Kitasatosporia species (submerged growth, 3 days) varied from $9: 1$ to $1: 1$. Only
TABLE 2. Proportions of LL-DAP and meso-DAP in different actinomycete species

\begin{tabular}{|c|c|c|c|}
\hline \multirow{2}{*}{ Organism ${ }^{a}$} & \multirow{2}{*}{ Collection no. } & \multicolumn{2}{|c|}{$\%$ DAP } \\
\hline & & LL & meso \\
\hline Actinoplanes auranticolor (S) & JCM 3038 & 10 & 90 \\
\hline Actinoplanes phiippinensis (S) & JCM 3001 & 14 & 86 \\
\hline Ampullariella digitata (S) & ATCC 15349 & 13 & 87 \\
\hline Faenia rectivirgula (S) & ATCC 33515 & 5 & 95 \\
\hline Kineosporia curantiaca $(\mathrm{S})$ & JCM 3230 & 63 & 37 \\
\hline Nocardioides albus (S) & ATCC 27980 & 95 & 5 \\
\hline Saccharomonospora viridis (S) & IFO 12207 & 8 & 92 \\
\hline Sporichthya polymorpha $(\mathrm{S})$ & JCM 3089 & 100 & 0 \\
\hline Streptomyces albus (S) & ISP 5313 & 95 & 5 \\
\hline Streptomyces albus $(\mathrm{L})$ & ISP 5313 & 88 & 12 \\
\hline Streptomyces cyaneus $(\mathrm{S})$ & JCM 4220 & 91 & 9 \\
\hline Streptomyces flaveus $(\mathrm{S})$ & A 2001 & 99 & 1 \\
\hline Streptomyces griseoruber $(\mathrm{S})$ & JCM 4200 & 95 & 5 \\
\hline Streptomyces griseus $(\mathrm{S})$ & ISP 5236 & 93 & 7 \\
\hline Streptomyces griseus $(\mathrm{L})$ & ISP 5236 & 93 & 7 \\
\hline Streptomyces roseiscleroticus $(\mathrm{S})$ & JCM 3104 & 85 & 15 \\
\hline Streptomyces purpureus $(\mathbf{S})$ & JCM 3172 & 84 & 16 \\
\hline Kitasatosporia griseola (S) & NRRL B-16229 & 16 & 84 \\
\hline Kitasatosporia griseola $(\mathrm{L})$ & NRRL B-16229 & 21 & 79 \\
\hline Kitasatosporia mediocidica $(\mathrm{S})$ & NRRL B-16109 & 37 & 63 \\
\hline Kitasatosporia mediocidica $(\mathrm{L})$ & NRRL B-16109 & 11 & 89 \\
\hline Kitasatosporia phosalacinea $(\mathbf{S})$ & NRRL B-16230 & 24 & 76 \\
\hline Kitasatosporia phosalacinea $(\mathrm{L})$ & NRRL B-16230 & 51 & 49 \\
\hline Kitasatosporia setae $(\mathrm{S})$ & NRRL B-16185 & 31 & 69 \\
\hline Kitasatosporia setae (L) & NRRL B-16185 & 22 & 78 \\
\hline
\end{tabular}

${ }^{a}$ Cells were harvested from solid (S) or liquid (L) media.

Kitasatosporia strains contained galactose in the hydrolysate.

Phage typing. All species of Kitasatosporia tested were resistant to polyvalent Streptomyces phage. These phage lyse some members of $S$. exfoliatus cluster 5 and a wide range of Streptomyces species, although some species, such as $S$. aureofaciens, were resistant to all phage (17).

rRNA probing. The results of the dot blot hybridization are shown in Fig. 1. The autoradiogram illustrates hybridization between crude RNA of Kitasatosporia species, selected streptomycetes, other actinomycetes, and the ${ }^{32} \mathrm{P}$ labeled probes. The universal probe (Fig. 1A) was used to show the presence and availability of RNA at each dot. The Streptomyces probe (Fig. 1B and C) has been shown to detect all members of the genera Streptomyces and Streptoverticillium (13) but fails to bind to RNA from all other members of the order Actinomycetales. Nonactinomycetes so far investigated also do not bind with the probe. The specificity of the probe is due to a single but highly unique base pair ( $\mathrm{C}$ at position 955 [E. coli numbering]). The washing temperature therefore has to be raised to $52^{\circ} \mathrm{C}$ (autoradiogram $\mathrm{C}$ in Fig. 1), which is only $2^{\circ} \mathrm{C}$ below the melting temperature of the homologous hybrid. The RNAs from all the Kitasatosporia strains, even at the highly stringent washing temperature (Fig. 1C), gave strong hybridization signals with the Streptomyces probe. RNAs from Streptomyces and Streptoverticillium species hybridized with the genus probe. It is evident that the $16 \mathrm{~S}$ rRNAs from the Kitasatosporia strains contain the Streptomyces-specific signature nucleotide at position 955 .

$16 S$ rRNA homologies. The sequence homology between the type species $K$. setae, $S$. albus, and Streptoverticillium baldaccii (Table 3) shows that there is a high degree of homology between $K$. setae and $S$. baldaccii. The latter 


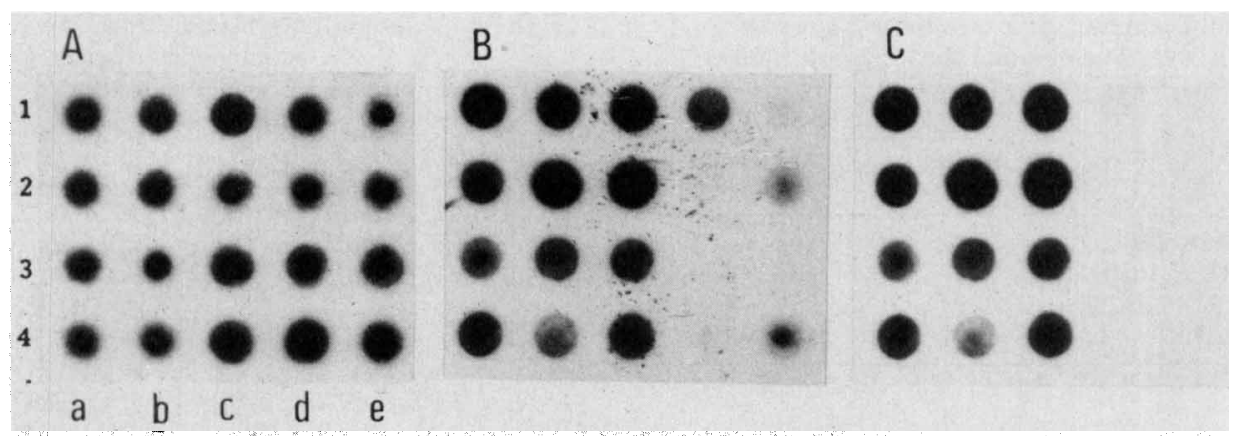

FIG. 1. Autoradiogram of dot blot hybridization between 16S rRNAs from strains of Kitasatosporia (lane a), Streptoverticillium (lane b), Streptomyces (lane c), and other actinomycetes (lanes $\mathrm{d}$ and e). (A) Eubacterial consensus probe $\left(28^{\circ} \mathrm{C}\right.$ hybridization temperature [ht], $34^{\circ} \mathrm{C}$ washing temperature [wt]); (B and C) Streptomyces probe. (B) $38^{\circ} \mathrm{C} \mathrm{ht}, 48^{\circ} \mathrm{C}$ wt. (C) Subsequent washing of filter B at $52^{\circ} \mathrm{C}$. Organisms: al, $K$. setae; a2, K. mediocidica; a3, K. phosalacinea; a4, K. griseola; b1, Streptoverticillium rubroverticillatum; b2, Streptoverticillium griseoverticillatum; b3, Streptoverticillium morokaense; b4, Streptoverticillium abikoense; c1, S. exfoliatus; c2, S. albus; c3, S. kauaiensis; c4, S. griseus; d1, Actinomadura malachitica; d2, Nocardia farcinica; d3, Dermatophilus congolense; d4, Frankia Mut 15; e1, Saccharothrix australiensis; e2, Streptosporangium amethystogenes; e3, Tsukamurella aurantiaca; 4 , Thermomonospora mesophila.

species has a higher degree of homology to $K$. setae than to other streptomycetes such as $S$. brasiliensis. K. setae is also closely related to $S$. lavendulae.

\section{DISCUSSION}

The taxonomic status of the genus Kitasatosporia is uncertain. The data presented here strongly indicate that members of this genus are closely related to members of the genus Streptomyces. We have provided definitive evidence that Kitasatosporia species can be grouped with Streptomyces and Streptoverticillium species on the basis of rRNA probe analysis. However, Kitasatosporia species identify phenotypically with Streptomyces and not with Streptoverticillium species. Conversely, streptoverticillia are susceptible to phage used to type the Streptomyces genus, but the species of Kitasatosporia tested were resistant. This may reflect differences in restriction enzymes or receptors. The cell wall analysis of Kitasatosporia species is confused but does indicate more meso-DAP than occurs in Streptomyces and Streptoverticillium species. Takahashi et al. (16) made a detailed study of the distribution of mèso- and LL-DAP in the different phases of growth. Streptomyces species contained only LL-DAP in aerial and vegetative mycelia, whereas $K$. setae, $K$. phosalacinea, and $K$. griseola contained LL-DAP in the aerial mycelium and meso-DAP in the vegetative mycelium. Only LL-DAP was detected in submerged and aerial spores. Nakamura et al. (7) reported differences in the ratio of LL- to meso-DAP when they analyzed submerged

TABLE 3. Homology of stretches of 16S rRNA (excluding all absolutely conserved positions) of selected Streptomyces species and $K$. setae

\begin{tabular}{|c|c|c|c|c|c|}
\hline \multirow[b]{2}{*}{ Organism } & \multirow{2}{*}{$\begin{array}{l}\text { Collection } \\
\text { no. }^{a}\end{array}$} & \multicolumn{4}{|c|}{ \% Homology with: } \\
\hline & & $\begin{array}{c}K . \\
\text { setae }\end{array}$ & $\begin{array}{c}S . \\
\text { baldaccii }\end{array}$ & $\begin{array}{c}S . \\
\text { lavendulae }\end{array}$ & $\underset{\text { albus }}{S .}$ \\
\hline$K$. setae & ATCC 33774 & & & & \\
\hline S. baldaccii & DPDU 0819 & 91.6 & & & \\
\hline S. lavendulae & ISP 5069 & 91.0 & 95.8 & & \\
\hline S. albus & ISP 5313 & 89.3 & 92.2 & 93.0 & \\
\hline S. brasiliensis & ATCC 23727 & 88.2 & 90.1 & 91.4 & 92.8 \\
\hline
\end{tabular}

${ }^{a}$ DPDU, Instituto di difesa delle Piante, Universita degli studi di Udine. Udine, Italy. growth. $K$. setae was found to contain the isomers in a ratio of $1: 3$, while two new species were described with ratios of $3: 1$. Other analyses of submerged growth have simply quoted the isomers to be present in equal amounts $(5,9)$. Obviously, the amounts of meso- and LL-DAP are variable and depend on the growth conditions and extent of sporulation. In the current study, meso-DAP was detected in significant amounts only by HPLC of extracts from submerged mycelium grown in tryptone soy broth. However, the results were variable and depended on the species examined and the extent of sporulation in the culture, as spores contained LL-DAP but mycelium contained predominantly meso-DAP. Differing amounts (1 to $16 \%$ ) of mesoDAP can be detected by HPLC in the whole-cell hydrolysates of mycelia from Streptomyces species. This suggests that the relative amounts of meso-DAP may not be a good criterion for the delimitation of a genus. Kitasatosporia species are also identified by the presence of galactose in whole-cell hydrolysates (9), which appears to be unaffected by the form of growth. This is the only distinguishing feature serving to separate Kitasatosporia from Streptomyces species. One of the other characteristics cited is the formation of submerged spores, but there have been reports clearly illustrating the formation of spores in submerged cultures of $S$. griseus (2).

Nomenclatural considerations. On the basis of $16 \mathrm{~S}$ rRNA homology, $K$. setae shows a high degree of homology to $S$. lavendulae and $S$. baldaccii. Streptoverticillium has been proposed as a synonym of Streptomyces on the basis of chemotaxonomic, biochemical, and phylogenetic similarities (22). Our data support a similar synonymy for Kitasatosporia.

The unification of Kitasatosporia with Streptomyces is proposed, and species transferred to the genus Streptomyces are $K$. griseola, $K$. mediocidicus, $K$. phosalacinea, and $K$. setae. The specific epithet for $K$. setalba was in violation of Rule 12a of the International Code of Nomenclature, and so the name was revised to $K$. setae (10). New combinations therefore include $S$. mediocidicus (Labeda, 1988) comb. nov., S. phosalacineus (Takahashi, Owai and Omura, 1984) comb. nov., and $S$. setae (Omura, Takahashi, Iwai and Tanaka, 1982) comb. nov.

For the Kitasatosporia species $K$. griseola, it is necessary to substitute a new specific epithet to produce $S$. griseolosporeus, because there is a senior homonym (see Rules 34a 
and 41a, International Code of Nomenclature of Bacteria [6]), S. griseolus, cited on the Approved List of Bacterial Names (11). The species " $K$. cystarginea" (4), "K. grisea," and "K. papulosa" (7) are not on the Approved List of Bacterial Names but are possible candidates for transfer to the genus Streptomyces.

Emendation of Streptomyces Waksman and Henrici 1943, $3^{339}{ }^{\mathbf{A L}}$. The description of the genus Streptomyces (18) together with emendation, including Streptoverticillium (22) and adding to the description to include Kitasatosporia (10), forms the basis for this emendation. Vegetative hyphae $(0.5$ to $0.2 \mu \mathrm{m}$ in diameter) produce a well-developed branched mycelium that rarely fragments. Reproduction by germination of the aerial, nonmotile spores. In most species, the aerial mycelium forms chains of spores, the surfaces of which are smooth, hairy, spiny, or warty. In other species, the aerial mycelium consists of long straight filaments bearing branches ( 3 to 6$)$ at regular intervals which are arranged in whorls (verticils). The appearance at ca. $\times 100$ magnification is of barbed wire. Each branch of the verticil produces at its apex an umbel of two or more spore chains, with spores lacking ornaments. A few species produce spores on the substrate mycelium or in liquid culture. Sclerotia, pycnidia, sporangiumlike bodies, and synnemalike structures may be formed. Form discrete and lichenoid, leathery or butyrous colonies. Initially, colonies are smooth surfaced but later develop a weft of aerial mycelium that may appear floccose, cottony, granular, powdery, or velvety.

Produce a wide variety of pigments responsible for the color of the vegetative and aerial mycelia. Colored diffusible pigments may also be formed. Many strains produce one or more antibiotics. Gram positive but not acid fast. Aerobes. Chemoorganotrophic, having an oxidative type of metabolism. Most strains use a wide range of organic compounds as sole sources of carbon for energy and growth, but some can utilize only a limited number of carbon sources. Substrate growth may develop under reduced oxygen tensions or increased carbon dioxide concentrations. Temperature optimum, 25 to $35^{\circ} \mathrm{C}$ at $\mathrm{pH} 5.5$ to 9.0 ; some species grow at temperatures within the psychrophilic and thermophilic ranges.

The cell wall peptidoglycan contains major amounts of LL-DAP in spores and hyphae; major amounts of meso-DAP may be detected in the vegetative hyphae. Galactose may be present in the whole-cell hydrolysate. They lack mycolic acids, contain major amounts of saturated, iso-, and anteisofatty acids, possess either hexa- or octahydrogenated menaquinones with nine isoprene units as the predominant isoprenolog, and have complex polar lipid patterns that typically contain diphosphatidylethanolamine, phosphatidyldiglycerol, phosphatidylinositol, and phosphatidylmannosides: They are widely distributed in soil, including compost. A few species are pathogenic for animals and humans; others are phytopathogens. The $\mathrm{G}+\mathrm{C}$ content of the DNA is 66 to $78 \mathrm{~mol} \%$ (at melting temperature).

Type species: $S$. albus (Rossi-Doria) Waksman and Henrici $1943,339$.

Description of $S$. griseolosporeus nom. nov. gri'se.o.lo. spo're.us. M.L. adj. griseolus, somewhat grey; M.L. n. spora, a spore; griseolosporeus, somewhat grey spored.

The species has been described as $K$. griseola by Takahashi et al. (16) and by Omura et al. (8). The new name is substituted as a result of homonymy (Rule 34a).

\section{ACKNOWLEDGMENTS}

We are grateful to D. P. Labeda for providing Kitasatosporia species and other cultures.

The work of E.S. was supported by a grant from the German Collection for Microorganisms, Braunschweig, Germany.

\section{REFERENCES}

1. Becker, B., M. P. Lechevalier, and H. A. Lechevalier. 1965. Chemical composition of cell-wall preparations from strains of various form-genera of aerobic actinomycetes. Appl. Microbiol. 13:236-243.

2. Glazebrook, M. A., J. L. Doull, C. Stuttard, and L. C. Vining. 1990. Sporulation of Streptomyces venezuelae in submerged cultures. J. Gen. Microbiol. 136:581-588.

3. Jorgensen, N. O. G. 1987 . Free amino acids in lakes: concentration and assimilation rates in relation to phytoplankton and bacterial production. Limnol. Oceanogr. 32:97-111.

4. Kusakabe, H., and K. Isono. 1988. Taxonomic studies on Kitasatosporia cystarginea $\mathrm{sp}$. nov., which produces a new antifungal antibiotic cystarginea. J. Antibiot. 41:1758-1762.

5. Labeda, D. P. 1988. Kitasatosporia mediocidica sp. nov. Int. J. Syst. Bacteriol. 38:287-290.

6. Lapage, S. P., P. H. A. Sneath, E. F. Lessel, V. B. D. Skerman, H. P. R. Seeliger, and W. A. Clark (ed.). 1975. International code of nomenclature of bacteria, 1975 revision. American Society for Microbiology, Washington, D.C.

7. Nakamura, Y., E. Ono, T. Kohda, and H. Shibai. 1989. Two new carbapenem antibiotic-producing actinomycetes: Kitasatosporia papulosa sp. nov. and Kitasatosporia grisea sp. nov. J. Antibiot. 52:18-29.

8. Omura, S., Y. Takahashi, and Y. Iwai. 1989. Genus Kitasatosporia, p. 2594-2598. In S. T. Williams, M. E. Sharpe and J. G. Holt (ed.), Bergey's manual of systematic bacteriology, 9th ed. The Williams \& Wilkins, Co., Baltimore

9. Omura, S., Y. Takahashi, Y. Iwai, and H. Tanaka. 1982. Kitasatosporia, a new genus of the order Actinomycetales. J. Antibiot. 35:1013-1019.

10. Omura, S., Y. Takahashi, Y. Iwai, and H. Tanaka. 1985 Revised nomenclature of Kitasatosporia setalba. Int. J. Syst. Bacteriol. 35:221.

11. Skerman, V. B. D., V. McGowan, and P. H. A. Sneath. 1980. Approved list of bacterial names. Int. J. Syst. Bacteriol. 30:225420 .

12. Stackebrandt, E., and O. Charfreitag. 1990. Partial 16S rRNA primary structure of five Actinomyces species: phylogenetic implications and development of an Actinomyces israeliispecific oligonucleotide probe. J. Gen. Microbiol. 136:37-43.

13. Stackebrandt, E., D. Witt, C. Kemmerling, R. Kroppenstedt, and W. Liesack. 1991. Designation of streptomycete $16 \mathrm{~S}$ and 23S rRNA-based target regions for oligonucleotide probes Appl. Environ. Microbiol. 57:1468-1477.

14. Staneck, J. L., and G. D. Roberts. 1974. Simplified approach to identification of aerobic actinomycetes by thin layer chromatography. Appl. Microbiol. 28:226-231.

15. Takahashi, Y., Y. Iwai, and S. Omura. 1983. Relationship between cell morphology and the types of diaminopimelic acid in Kitasatosporia setalba. J. Gen. Appl. Microbiol. 29:459-465.

16. Takahashi, Y., Y. Iwai, and S. Omura. 1984. Two new species of the genus Kitasatosporia, Kitasatosporia phosalacinea sp. nov and Kitasatosporia griseola sp. nov. J. Gen. Appl. Microbiol. 30:377-387.

17. Wellington, E. M. H., and S. T. Williams. 1981. Host ranges of phage isolated to Streptomyces and other genera. Zentralbl. Bakteriol. Abt. 1 11(Suppl.):93-98.

18. Williams, S. T., M. Goodfellow, and G. Alderson. 1989. Genus Streptomyces Waksman and Henrici $1943,339^{\mathrm{AL}}$, p. $2452-2492$. In S. T. Williams, M. E. Sharp, and J. G. Holt (ed.), Bergey's manual of systematic bacteriology, 9 th ed. The Williams \& Wilkins Co., Baltimore.

19. Williams, S. T., M. Goodfellow, G. Alderson, E. M. H. Wellington, P. H. A. Sneath, and M. J. Sackin. 1983. Numerical classification of Streptomyces and related genera. J. Gen. Mi- 
crobiol. 129:1815-1830

20. Williams, S. T., M. Goodfellow, E. M. H. Wellington, J. C. Vickers, G. Alderson, P. H. A. Sneath, M. J. Sackin, and A. M. Mortimer. 1983. A probability matrix for identification of some streptomycetes. J. Gen. Microbiol. 129:1815-1830.

21. Witt, D., W. Liesack, and E. Stackebrandt. 1989. Identification of streptomycetes by $16 \mathrm{~S}$ rRNA sequences and oligonucleotide probes, p. 679-684. In T. Hattori, Y. Ishida, Y. Maruyama, R. Morita, and A. Uchida (ed.), Recent advances in microbial ecology. Japan Scientific Society Press, Tokyo, Japan.

22. Witt, D., and E. Stackebrandt. 1990. Unification of the genera Streptoverticillium and Streptomyces and amendation of Streptomyces Waksman and Henrici 1943, 339 ${ }^{\mathrm{AL}}$. Syst. Appl. Microbiol. 13:361-371. 